Article

\title{
Education in Confinement: The Reintegration of Young People in Prison in La Araucanía, Chile
}

\author{
Claudia Huaiquián-Billeke ${ }^{1, *}$, Violeta Sánchez-Toledo ${ }^{2}$, Romina Quilodrán-Contreras ${ }^{3}$ and Juan Vera-Urra ${ }^{4}$ \\ ${ }^{1}$ Department of Educational Sciences, Faculty of Education, Catholic University of Temuco, Chile; \\ E-Mail: chuaiquian@uct.cl \\ 2 Scole Creare School, Chile; E-Mail: violetasanchezt@gmail.com \\ ${ }^{3}$ Integra Foundation, Chile; E-Mail: rominavquilodran@gmail.com \\ ${ }^{4}$ Education Department, Municipality of Temuco, Chile; E-Mail: juan.antonio.vera.u@gmail.com \\ * Corresponding author
}

Submitted: 14 June 2021 | Accepted: 12 July 2021 | Published: 13 October 2021

\begin{abstract}
This article addresses the social reintegration of young people studying in the prison of La Araucanía, Chile. Our objective is to describe the social representation of young people between 19 and 29 years old, who are currently serving a custodial sentence, in their reintegration process after secondary education. We start off with the acknowledgement that both social mobility and educational career are historically marked by the reproduction of sociocultural inequality: Educational structures do not fulfill the mission of providing tools for a persons' life. Our article is based on a unique case study in which a current phenomenon is investigated; in this case, social reintegration within an authentic context-prison. Semi-structured interviews were applied during our research and participants' narratives were methodologically triangulated. Our article concludes that, given the presence of homogenizing and inefficient study plans, young people demand deep changes that are linked to a social pedagogy, which values their skills and life project through an awareness process. This process would enable them to explore their reality and cultural action in order to become conscious young people and co-creators of their future once in freedom.
\end{abstract}

\section{Keywords}

correctional education; educational lag; inclusive education; prison education; social mobility; social reintegration; students' motivation

\section{Issue}

This article is part of the issue "Promoting Inclusion and Equality in Education" edited Allen Thurston (Queen's University Belfast, UK) and Tien-Hui Chiang (Anhui Normal University, China).

(C) 2021 by the authors; licensee Cogitatio (Lisbon, Portugal). This article is licensed under a Creative Commons Attribution 4.0 International License (CC BY).

\section{Introduction}

We begin by clarifying the question: What does imprisonment mean? Its distinctive features are found inside prisons and, therefore, daily life under imprisonment is determined by the characteristics and routines of a prison regime based on segregation and security (Foucault, 2002). The reality of imprisonment in Chile is characterized by being at the base of a punitive society in which power control mechanisms categorize the person who breaks the law as a criminal, as an enemy of society, and in which crime is a civil war act, an attack on society. This makes it possible to justify public action as a defense mechanism that is complemented by imprisonment by suspending civil rights, erasing the offenders' citizenship, imposing an invisible power mark on him; a change of status that imposes a persons' diminution (Foucault, 2016).

Social reintegration in Chile has a utopian character because the Chilean state has not assumed its responsibility to provide an educational policy relevant to its reality. That is also one of the reasons why we decided to address this issue in our research. The problem of 
imprisonment constitutes an invisible mark of power sovereignty over a person. The analysis of a penal system reveals the nature in which a society develops around power. Crime is an attack on society that justifies daily non-criminal coercion; a form of control that is linked to punishment through institutions that not only subtract the person but also set productive and normalization structures (Foucault, 2016).

Education within confinement contexts is a concept used in Chile when accessing education in the penitentiary space, in institutions for young people, and in closed addiction care centers. The goal is to safeguard peoples' human rights beyond the judicial condition in which they are found. Both social mobility and educational trajectory are historically marked by the reproduction of sociocultural inequality: Educational structures do not fulfill the mission of providing tools for a persons' life.

According to statistical data from the Chilean prison system in 2021, there are 45,176 people in prison at present. In Temuco, $47 \%$ of the incarcerated population corresponds to young people, which is a representative sample that reflects the reality of the prison system in Chile. For this research, the sample inclusion criteria were the following: They had to be young people (men) who were serving a sentence corresponding to crimes of greater social connotation (robbery, theft, sexual crimes, homicide, drugs, and domestic violence); they had to be attending secondary education; their age range had to fluctuate between 19 to 29; and they had to be governed by behavior standards of the penitentiary center (Chilean Gendarmerie, 2021; National Statistics Institute, 2019).

Imprisonment pedagogical meanings, according to Bourdieu's postulates, are evident in this social reality, in which pedagogical action is also a selection of meanings through the contents, study plans, and educational guidelines. People who break the law are imprisoned. Like all social agents, they have different types of social, economic, cultural, and symbolic capital. In Bourdieu, capital is understood as a type of value, which is a wealth of the field of struggles, and its appropriation and control is the objective of the struggle of forces within each space. Thus, each capital will have a specific value within the space that constitutes each field. However, there are some capitals that have certain value in different social spaces. These are: economic capital (money, properties, goods, investments), social capital (relationships, contacts, kinships), cultural capital (information, knowledge, socially validated knowledge), and symbolic capital (honesty, respect referred to honor, social recognition; Bourdieu, 2008).

The concept of imprisonment points out only to those total institutions that share logic and operating practices, which correspond to a penitentiary center, whose purpose is the total control of young people, and security is its axis. Constant contradictions are addressed in the Chilean prison system and educational centers, because management decisions depend on the institution that establishes security standards (Gaete, 2018).
Education is a process that must be conceived for young people as a permanent commitment to humanization and their life project (Freire, 1970). Our object of study in this article is the process of social reintegration of young people in prison, and how the educational process responds to their needs by analyzing the relevance of study plans. The research participants are young people who are in an educational process while in confinement.

The education of young people and adults in Chile is ruled by study plans. A utopian proposal is clearly visualized in this discourse, which promises to guarantee social reintegration; however, reality does not reflect this. Therefore, it is impossible for education to become a tool for a persons' growth (Lucio-Villegas, 2017).

When reviewing scientific studies on incarceration, it was found that the learning experiences of young people in prison account for a diversity of jobs, including artistic and sports competencies that they need to acquire, which are not mobilized or included in the study plans (Sandoval \& López de Maturana, 2017).

The different perspectives of prison education subjectively affect and resignify the time of confinement, which does not lead to reducing the crimes committed by young people, but rather promotes the possibility of solving the problems that threaten social peace (Schneider, 2018).

It is pertinent to rethink the study plans, since they are not situated in the reality of incarceration, hindering the possibilities of social reintegration of young people, therefore, the challenge is to guarantee equity and equal opportunities. Paradoxically, the mission of both institutions has different operating logics, since one position promotes the principle of freedom, while the other conditions and limits it (Echegaray, 2018; Francisco \& Sieiro, 2017).

Preparing students for a life in freedom is a challenge for prison education. Young people need to develop a genuine prosocial behavior, which leads them to motivation, autonomy, responsibility, and adherence to educational processes with different purposes (Lorenzo et al., 2017). The challenge of transforming prisons into a place that allows social mobility and that meets standards of educational excellence requires permanent learning. In this sense, education in prison is both for the young people who are actually "learning" and those who belong to the educational community more broadly (De Maeyer, 2019).

A fundamental aspect is the permanent education of those who make up the educational community: teachers, directors, and prison administrators. The latter play an essential role since they are the ones who are in direct contact with young people in prisons, therefore, their continuous education is a priority, since each gesture or word directly expressed influences the educational process (De Maeyer, 2019). The study plans of education in imprisonment must pay attention to young people's knowledge and self-assessment, foster their hopes, and 
guide them in their life project formation. It is important to refer to the fact that prisons must have specialized personnel, that is, experienced professionals who provide adequate support to young people.

This article presents the findings of the reality of youth incarceration in La Araucanía. Our key focus is the social representations of young people in their reintegration process and the relevance of the study plans to the educational reality.

\section{Theoretical Framework: The Challenge of Social Reintegration in Prison}

Imprisonment has been historically addressed to understand the treatment and conditions, from the perspective of correctionalist characters, and re-socializing, allowing socially adaptive behavior (Rubio, 2012).

According to Foucault (2002), the penitentiary model has its point of origin in the sanction mechanisms that seek to correct a person's behavior through selfmanagement. Behavior is imposed through permanent surveillance. Power seeks to act through the surveillance, control, and correction of citizens.

In this article, to understand the process of social reintegration in imprisonment, the Chilean prison model is analyzed. This model reflects the reality in Latin America based on a legislative framework that established unattainable ideals and endorsed such commitments as the right of all people to be treated with dignity, respect for everyone's ideological freedom and personal privacy, ensure that everyone has access to information, education, and culture in legal conditions (UN General Assembly, 1948).

Social reintegration is considered a process of systemic actions that contribute to the reduction of recidivism and promote social mobility. This process begins during the execution of the sentence and continues when the young people resume their life in their community. It is characterized by the development of individual, social and work skills. However, in practice, the proposed actions lack a humanizing sense and socially adaptive behaviors (Ministry of Justice and Human Rights, 2021).

The access of incarcerated young people to the educational system occurs with a series of significant barriers that hinder their inclusion processes, especially to those who are in an irregular situation facing difficulties to enter the school system and progress (Ministry of Education of Chile, 2021).

The normative frameworks that study plans for the education of young people in prison establish must be flexible when considering the educational and life trajectory peculiarities, guaranteeing security and social reintegration.

Educational centers are obliged to modify their regulations, granting various opportunities that contribute to the development of cultural capital (Caride \& Gradaille, 2013; Government of Chile, 2016).
The process of social reintegration should consider that young people have needs, interests, and specific difficulties, and that only through education process of social mobility is enriched (Brosens et al., 2020).

If we analyze the foundations of the critical pedagogy school in Latin America, its proposal allows the possibility of interfering reality to transform it, providing educational tools for freedom and relating the perspective of access to education, which promotes equal opportunities. The approaches differ from the educational reality of young people in prison because they are not considered in the existing study plans (Freire, 1969; Murillo, 2017; Schmelkes \& Street, 2015).

Education based on social pedagogy implies the true value of a person: a conscious being who is constituted in its transcendence, intentionality, and openness, since it is open to the whole world. A person is realized in human acts; they are constructed in a cultural context (Fuentes, 2009; La Chica, 2015; Scheler, 2001). In this way, social pedagogy trains young people in awareness, gives them the tools and prepares them in action and permanent reflection (Correa, 2012).

To investigate what young people think of their educational reality in imprisonment, it is pertinent to access their social representations, which supposes a subjectsubject dialogical link, as a proper construction of a sense of mobile identities which fluctuate within a framework of social performance (Weisz, 2017). For a better understanding, the three types of social representations must be clarified. These are: (1) emancipated representations, which are typical of groups with new visions and criteria of the world; they bring with them the seed of a possible change, are flexible and dynamic over time; (2) hegemonic representations, which are typical of identity phenomena and act as a map-guide, almost unconsciously, upon the behavior of communities, ethnic groups, and nations; and (3) controversial representations, which are the result of manifest antagonism among specific groups that are configured around relevant facts or objects that constitute the center of intergroup conflicts (Moscovici, 1985).

\section{Method}

This is a qualitative study from the point of view of the presence of researchers, who investigate the sociocultural particularities of young people in prison (Gibbs, 2012).

The purpose of this study was to discover and understand the reality of young peoples' social representations regarding their social reintegration and the relevance of their study plans during incarceration. Emphasis was placed on young people qualities and the predominance of subjectivities, underlining the nature of the socially constructed reality in imprisonment (Flick, 2007).

The study sample was a total of 25 young people (men) who were attending secondary education. Their age range is from 19 to 29 years old. Participants were 
categorized with good behavior according to prison regulations and manifested the desire to participate voluntarily by signing an informed consent.

This is a dense descriptive study-a unique case study design focused on the prison of the city of Temuco, an institution that granted us access to the application, collection, and interpretation of the stories of the young people in prison.

The semi-structured interviews were approved by the scientific committee of the Universidad Mayor de Temuco. The interview scheme was designed in an open way and validated by expert judgments. Semi-structured interview type was chosen, with the purpose that the researcher, through questions, promotes the description of daily experiences of young people in prison (Kvale, 2011).

The ethical dimension of this study provided security in the confidential treatment of information and private data, through the informed consent of voluntary participants (Mansilla \& Huaiquián, 2020). Another ethical aspect was a strict interaction protocol authorized by the regional direction of the penitentiary center and the Directorate of Municipal Educational Administration of Temuco (González, 2002).

The analysis of the research data is qualitative; version 8.0 of the Atlas.ti software was used for open coding and grouping the stories of young people in prison into categories (Flick, 2007).

This software allows expressing the circular meaning of qualitative analysis and gives the possibility of incorporating the data sequentially, without the need to col- lect all the material at the same time. For this reason, the software allows us to carry out the theoretical sampling necessary to carry out the analysis. Axial coding was implemented, which is the process of relating subcategories with a category, building code networks that emerge from the established categories to finally integrate and refine these categories with the aim of building theory (Mansilla \& Huaiquián, 2020).

\section{Discussion of Results}

To gain a deeper understanding, the researchers chose to answer: What are the social representations of young people about the process of social reintegration? The answers allow us to approach the life trajectories of young people in prison and the consequences of their social behavior in all its complexity. This investigative process review aims at projecting imprisoned young people in the exercise of their role as a citizen after the completion of their sentence. Therefore, it allows the construction of public policies that contribute to social reintegration. The most representative codes are: cultural capital, life project in freedom, awareness, educational backwardness and free time (see Figure 1).

The cultural capital code can be found in the following textualities:

What I learn [teaches me] different lessons: the use of money, moving around the city. I think even to go buy food. To take the bus. (speaker 11)

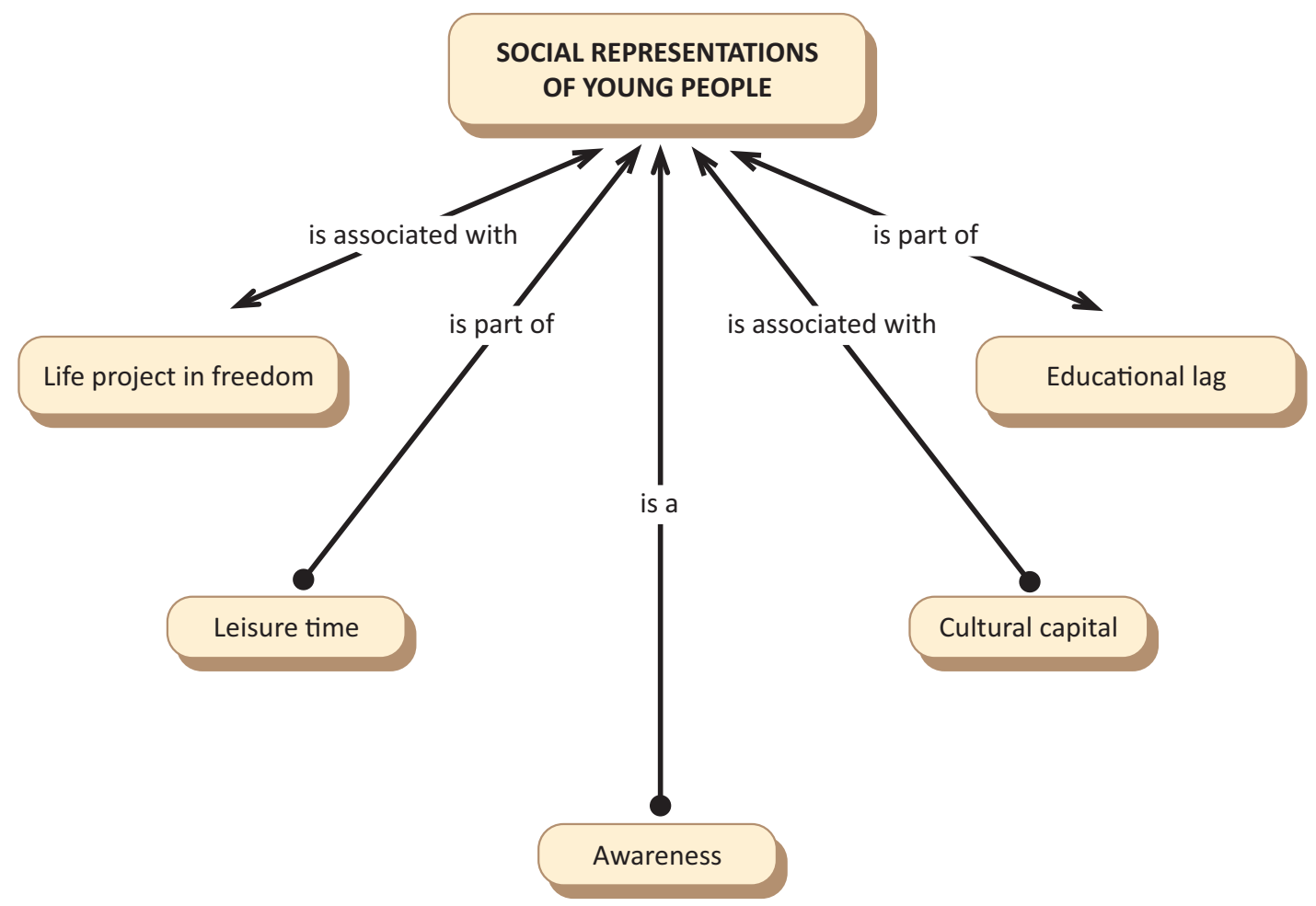

Figure 1. Network, social representations of the process of reintegration in imprisonment in La Araucanía. Analysis network built with Atlas.ti 8.0 software. 
If you do not know which bus to take, learning the use of [the] language helps you communicate and ask questions, request information from the driver, for example, then you have to know about mathematics, also to understand an address. (speaker 17)

Language helps you write well and communicate in a different way, to develop yourself in society. (speaker 20).

The project code of life in freedom is visualized in the following passages:

Now that I am incarcerated, I think it is necessary to educate myself. I would like my wife and I to study a short career and get a better job, to improve our quality of life together. (speaker 7)

The consciousness code is visualized in the following passages:

Now that I am in prison, I project my life when I regain my freedom; I am going to worry about the values my son learns, so he does not make the same mistakes as me. (speaker 14)

I think, for one, despite one's age, one never stops learning, but what I would like to learn, to value the people that I have by my side. If one learned to read what people feel. I want to be aware of what I have and I need to value. (He/she) is sad because I can see it in his/her mood. (speaker 16)

I want to understand people's reality, be more of a person, be more understanding. (speaker 8)

The educational lag code is reflected in the following passages:

Because society demands you to continue your studies, to learn English, to learn mathematics. The teachers teach you so that you can express yourself better, but they demand of you things that you had not seen before, the teachers or they repeat the subjects, which I have not managed to understand. (speaker 6 )

They are constantly reinforcing things that I have not learned. I feel that I am behind if I compare myself with my mates. (speaker 11)

The leisure time code is reflected in the following textualities:

I value gym hours to de-stress. I like to play ping pong. I am interested in exercising or having an instructor like we had in high school, when I was not in prison. (speaker 3)
I like to attend music workshops, the intention to learn to play guitar. (speaker 8 )

\section{Conclusions}

Scheler's (2001) essentialist axiological approach was visualized in the codes that were raised. The participant's social representations focused on education as a means for the formation of a personal life project, based on values and for life.

Social representations are particularly established as the set of mechanisms carried out by social, cultural, and psycho-symbolic studies; therefore, they have the ability to enhance the deployment of common sense and subjectivity, which are characteristics of qualitative research, with the purpose of understanding and interpreting the sense and meaning that the participants give to the social reintegration process. Observing the reality of young people who are imprisoned and analyzing the purposes of education represent a challenge and a form of action that emerges from critical reflection and the permanent struggle to provide opportunities for social mobility and that represents the need the participants feel.

Analysis of the data reveals a limited educational proposal on imprisonment. To achieve this reality, an educational process aimed at developing knowledge and skills on a personal level is pertinent. Therefore, the priority of education in imprisonment is the formation of young people life projects to achieve their social reintegration. In this sense, for young people learning goes beyond the acquisition of knowledge, since it requires transformation into action, which in turn becomes learning.

In imprisonment education, study plans with a socioeducational perspective are valued because from imprisoned young peoples view, it is considered a protective and integral factor in the formation of those who are educated in this context. The effective implementation of the study plans for incarcerated young people requires the commitment of all the actors within the educational center, overcoming the obstacles given by society itself that provoke confrontation between the different missions and visions, such as security versus rights, punishment versus rehabilitation, bearing in mind that educating in incarceration, although it has an associated economic cost, hardly will this be greater than the social cost of crime (Iturralde, 2018).

Educational lag is a pending task for the authorities, since it implies a social problem that is not eradicated only through palliative actions. This must be analyzed from a qualitative and critical approach that allows a review of imprisonment policies, since young people are made invisible by the dominant groups who design educational policies (Frausto, 2017; Tilley, 2019).

The social reintegration of young people in prison must address diversity and its implications in participation in order for young people to achieve their freedom. Freedom does not have to do with being physically enclosed; rather it is found from within a person, in their 
human essence. This idea is reinforced through education (Boff, 2002; Panitsides \& Moussiou, 2019).

The social representations that were revealed regarding the implementation of study plans, from imprisoned young peoples' perspective, are emancipated representations. Given the possibility of a change in the educational center, the data coincide in prioritizing the design of new study plans which are flexible to the times and the local context. The social account considers that the study plans demanded by young people must consider their motivations and urgently integrate leisure and recreation spaces. Its cultural capital arises in the training actions that were received from family upbringing and the cultural environment (Bourdieu, 2008). Young people, lacking the cultural capital demanded by the knowledge society, become oppressed young people in which the socio-political system does not allow them social mobility, so the only option for human liberation is through a radically transformative praxis (Freire, 1969).

Young peoples' social representations are limited by a low cultural capital that restricts their motivations towards the construction of a life project in freedom. That is linked to the life project that is conceived as a structure made up of real expectations and strategies that are expected within a social context. The life project is based on the options that a young person has and that are the expression and guarantee of freedom (Sánchez-Cascado, 2020). In this sense, the life project represents the relationship of a person with themselves and with the community to which they belong, defining the possibilities to achieve those aspirations; therefore, this requires a process of consciousness through which young people explore their reality and cultural action in order to be conscious young people and co-creators of their future in freedom. Hegemonic social representations are appreciated in the valuation of young people to traditional disciplines such as language and mathematics, which allow cultivating the human essence and cultural capital, granting access to knowledge as a way to the liberation process from within (García-Yepes, 2017).

There is a permanent tension between social poverty and the state responsibility to educate in imprisonment. Education must not bear the consequences but must guarantee young people to safeguard their human dignity by having their right to education, contributing to a just society. Education is a social and cultural political practice, which makes us frequently rethink the questioning of the forms of subordination that create inequities in imprisonment contexts (Barragá et al., 2018).

Imprisonment education requires rethinking. To achieve a true transformation, there must be a change of thought, which is reflected in educational practice, guaranteeing a deep socialization of the person through social pedagogy. This allows the person in the course of their life to integrate cultural forms and contents into their personality and gradually incorporate themselves into society.

\section{Acknowledgments}

Regional Direction of Penitentiary System of Chile (Chilean Gendarmerie), Municipal Education Department of the city of Temuco.

\section{Conflict of Interests}

The authors do not declare conflicts of interest.

\section{References}

Barragá, A., Carabajo, I., \& Quinto, D. (2018). Pedagogía crítica [Critical pedagogy]. Revista Científica Mundo de la Investigación y el Conocimiento, 2(3), 465-478. https://doi.org/10.26820/recimundo/2. (3).julio.2018.465-478

Boff, L. (2002). El águila y la gallina: Una metáfora de la condición humana [The eagle and the chicken: A metaphor for the human condition]. Trotta.

Bourdieu, P. (2008). Capital cultural, escuela y espacio social [Cultural capital, school and social space]. Siglo XXI.

Brosens, D., Croux, F., Claes, B., Vandevelde, S., \& De Donder, L. (2020). An organizational analysis of foreign national prisoners' participation possibilities in Flanders (Belgium). Journal of Prison Education and Reentry, 6(2), 144-161. https://doi.org/10.25771/mh4f0996

Caride, J., \& Gradaílle, R. (2013). Educar en las cárceles: Nuevos desafíos para la educación social en las instituciones penitenciarias [Educating in prisons: New challenges for social education in penal institutions]. Revista de Educación, Ministerio de Educación Cultura y Deporte, Gobierno de España, 360(3), 36-47. https://doi.org/10.4438/1988-592XRE-2013-360-219

Chilean Gendarmerie. (2021). Estadística general [General statistics]. Gendarmería de Chile. https://www. gendarmeria.gob.cl/estadisticaspp.html

Correa, L. (2012). La enseñanza de la filosofía y sus contribuciones al desarrollo del pensamiento [The teaching of philosophy and its contributions to the development of thought]. Sophia, Colección de Filosofía de la Educación, 5(12), 67-82. https://www.redalyc. org/articulo.oa?id=441846101005

De Maeyer, M. (2019). L'éducation en prison à la périphérie de l'éducation pour tous [Education in prison on the periphery of education for all]. International Review of Education, 65(5), 811-832. https:// doi.org/10.1007/s11159-019-09800-6

Echegaray, M. (2018). Educación en contextos de encierro: Análisis de los problemas de gobernabilidad [Education in confinement contexts: Analysis of governance problems]. Archivos de Criminología Seguridad Privada y Criminalística, 20(2), 7-19. https://dialnet.unirioja.es/servlet/articulo?codigo= 6370958 
Foucault, M. (2002). Vigilar y castigar. Nacimiento de la prisión [Watch out and punish. Birth of the prison]. Siglo XXI.

Foucault, M. (2016). La sociedad punitiva, curso en el Collège de France (1972-1973) [The punitive society, course at the Collège de France (1972-1973)]. Fondo de Cultura Económica de Argentina.

Flick, U. (2007). Introducción a la investigación cualitativa [Introduction to qualitative research]. Morata.

Francisco, J., \& Sieiro, F. (2017). Educação não-escolar no desenvolvimiento de medidas socioeducativas em instituições de internação para jovens em conflito com a lei [Non-school education in the development of socio-educational measures in detention institutions for young people in conflict with the law]. Laplage em Revista, 3(3), 221-234. https://dialnet. unirioja.es/servlet/articulo?codigo $=6192039$

Frausto, A. (2017). El rezago educativo total y su atención en México [The total educational gap and its attention in Mexico]. Revista Latinoamericana de Estudios Educativos (México), 47(2), 41-58. https://www. redalyc.org/articulo.oa?id=27052400003

Freire, P. (1969). La educación como práctica de la Libertad [Education as a practice of freedom]. Siglo XXI.

Freire, P. (1970). Pedagogía del oprimido [Pedagogy of the oppressed]. Paidós.

Fuentes, J. (2009). La impostura freudiana: Una mirada antropológica crítica sobre el psicoanálisis freudiano como institución [The Freudian imposture: A critical anthropological look at Freudian psychoanalysis as an institution]. Encuentro.

Gaete, M. (2018). Pedagogía en contextos de encierro en américa latina: Experiencias, posibilidades y resistencias [Pedagogy in confinement contexts in latin america: Experiences, possibilities and resistance]. RIL Editores.

Gibbs, G. (2012). El análisis de datos cualitativos en investigación cualitativa [Qualitative data analysis in qualitative research]. Morata.

García-Yepes, K. (2017). Procesos de integración social de inmigrantes en escuelas de Huelva, España: Diversidad cultural y retos educativos [Processes of social integration of immigrants in schools in Huelva, Spain: Cultural diversity and educational challenges]. Alteridad, Revista de Educación, 12(2), 144-154. https:// doi.org/10.17163/alt.v12n2.2017.05

Government of Chile. (2016). Crea la subsecretaría de derechos humanos y adecúa la ley orgánica del ministerio de justicia [Creates the under secretariat for human rights and adds the organic law of the ministry of justice]. Biblioteca Congreso Nacional de Chile. https://www.bcn.cl/leychile/navegar?idNorma= 1086063

González, M. (2002). Aspectos éticos de la investigación cualitativa [Ethical aspects of qualitative research]. Revista Iberoamericana de Educación, 29(2), 85-103. https://rieoei.org/historico/documentos/ rie29a04.PDF
Iturralde, C. (2018). La educación superior en las cárceles. Los primeros pasos del Ecuador [Higher education in prisons. The first steps of Ecuador]. Alteridad, Revista de Educación, 13(1), 84-95. https://doi.org/ 10.17163/alt.v13n1.2018.06

Kvale, S. (2011). Las entrevistas en investigación cualitativa [Qualitative research interviews]. Morata.

La Chica, M. (2015). La noción de persona y los procesos de despersonalización del ser humano a través del holocausto nazi. Una mirada antropológico-filosófica sobre el genocidio [The notion of person and the processes of depersonalization of the human being through the Nazi Holocaust. An anthropologicalphilosophical look at genocide]. En-claves del Pensamiento, 9(17), 87-111. http://www.scielo.org.mx/ scielo.php?script=sci_arttext\&pid=\$1870879X2015000100087\&lng=es\&tlng=es

Lucio-Villegas, E. (2017). La desaparición - o tal vez no - de la educación de jóvenes adultas. El caso de Andalucía [The disappearance-or perhaps not-of young adult education. The case of Andalusia]. Educação. Revista do Centro de Educação, 42(1), 33-44. https://doi.org/10.5902/1984644426372

Lorenzo, M., Varela, C., \& García, J. (2017). La universidad en un centro penitenciario: Una razón más para la Pedagogía [The university in a penitentiary center: One more reason for pedagogy]. Revista de Estudios e Investigación en Psicología y Educación, 2017(8), 62-67. https://doi.org/10.17979/reipe.2017.0.08. 2472

Mansilla, J., \& Huaiquián, C. (2020). Logos y Tecné. Metodología de la Investigación [Logos and tecné. Investigation methodology] (2nd ed.). Internauka.

Ministry of Education of Chile. (2021). Coordinación nacional de educación de personas jóvenes y adultas [National coordination of education for young people and adults]. https://epja.mineduc.cl/presentacion/ presentacion

Ministry of Justice and Human Rights. (2021). Identificación de necesidades de intervención y brechas en la oferta de programas de reinserción destinados a la población vigente en Gendarmería de Chile [Identification of intervention needs and gaps in the offer of reintegration programs aimed at the current population in the Chilean Gendarmerie]. https://www.minjusticia.gob.cl/identificacion-denecesidades-de-programas-intervencion-en-lapoblacion-penal

Moscovici, S. (1985). Psicología social I. Influencia y cambio de actitudes. Individuos y grupos [Social psychology I. Influence and change of attitudes. Individuals and groups]. Paidós.

Murillo, W. (2017). Un modelo pedagógico de educación universitaria a distancia para estudiantes en prisión: Perspectivas y desafíos [A pedagogical model of distance university education for students in prison: Perspectives and challenges]. Revista Posgrado y Sociedad, 15(2), 49-56. https://dialnet.unirioja.es/ 
servlet/articulo?codigo $=6228715$

National Statistics Institute. (2019). Estadísticas policiales, 2019 [Police statistics, 2019]. National Institute of Statistics. https://www.ine.cl/docs/defaultsource/estadisticas-policiales/publicaciones-yanuarios/estadisticas-policiales/2019-informeanualestad\%C3\%ADsticaspoliciales.pdf?sfvrsn= b82b340a_2

Panitsides, E., \& Moussiou, E. (2019). What does it take to motivate inmates to participate in prison education? An exploratory study in a Greek prison. Journal of Adult and Continuing Education, 25(2), 157-177. https://doi.org/10.1177/1477971419840667

Rubio, H. (2012). Breve reseña histórica y conceptual de la prisión [Brief historical and conceptual overview of prison]. Ciencia Jurídica, 2(1), 11-28. https://dialnet. unirioja.es/servlet/articulo?codigo $=4216857$

Sánchez-Cascado, P. (2020). El daño al proyecto de vida en la corte interamericana de derechos humanos a la luz del pensamiento político de J. Shklar [The damage to the life project in the inter-american court of human rights in the light of the political thought of J. Shklar]. Andamios, 17(42), 147-166. https://doi. org/10.29092/uacm.v17i42.738

Sandoval, E., \& López de Maturana, S. (2017). Desafíos educativos en torno a las experiencias de aprendizaje mediado con adolescentes infractores de ley [Educational challenges around mediated learning experiences with adolescent offenders]. Revista de Currículum y Formación de Profesorado, 21(2), 377-391. https://recyt.fecyt.es/index.php/profesorado/ article/view/59465
Scheler, M. (2001). El formalismo en la ética y la ética material de los valores [The formalism in ethics and the material ethics of values] (3rd ed). Caparrós.

Schmelkes, S., \& Street, S. (2015). Tres visiones de la educación de adultos en México: Los funcionarios, los instructores y los adultos [Three visions of adult education in Mexico: Officials, instructors and adults]. Revista Latinoamericana de Estudios Educativos (México), 45(3), 181-218. https://www.redalyc. org/articulo.oa?id=27041543007

Schneider, G. (2018). De la educación en cárceles de Argentina y España. Entre el enfoque de derechos y el tratamiento penal [On education in prisons in Argentina and Spain. Between the rights approach and criminal treatment]. Revista de Estudios Marítimos y Sociales, 12(1), 10-23. https://estudios maritimossociales.org/archivo/rems-12/schneiderpdf

Tilley, S. (2019). The role of critical qualitative research in educational contexts: A Canadian perspective. Educar em Revista, 35(75), 155-180. https://doi.org/ 10.1590/0104-4060.66806

UN General Assembly. (1948). Universal declaration of human rights. https://www.un.org/en/about-us/ universal-declaration-of-human-rights

Weisz, C. (2017). La representación social como categoría teórica y estrategia metodológica [Social representation as a theoretical category and methodological strategy]. Revista CES Psicología, 10(1), 99-108. https://revistas.ces.edu.co/index.php/psicologia/ article/view/3781

\section{About the Authors}
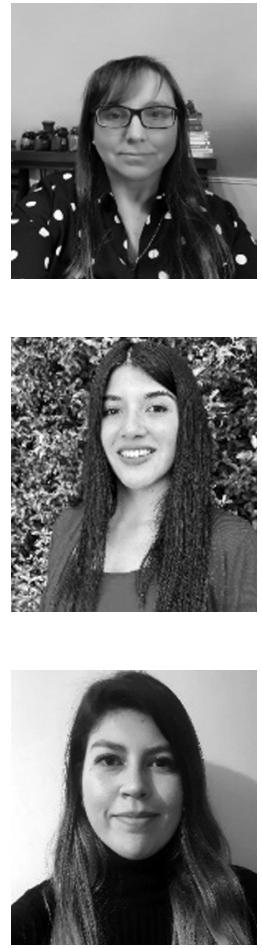

Claudia Huaiquián-Billeke (PhD in educational sciences), is an associate professor of the Department of Educational Sciences, Faculty of Education (Catholic University of Temuco, Chile), as well as the director of the Center for Assessment and Early Stimulation at the Catholic University of Temuco (CEETU-UCT). Her line of educational research is based on diversity and social justice.

Violeta Sánchez-Toledo (MS in education) is a teacher of differential education at Scole Creare School, with a specialty in transitory special educational needs and mental deficiency (Catholic University of Temuco, Chile). She has a master's degree in educational sciences, specialized in curriculum and evaluation (Mayor University, Chile).

Romina Quilodrán-Contreras (MS in education) is a kindergarten educator at Integra Foundation (Temuco, Chile). She also has a master's degree in educational sciences, specialized in curriculum and evaluation (Universidad Mayor, Chile). 


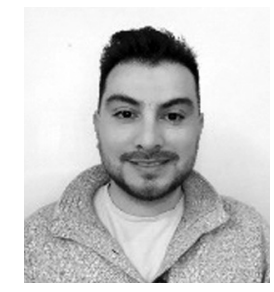

Juan Vera-Urra (MS in education) is a titular teacher at the Department of Education of the municipality of Temuco. He has a master's degree in educational sciences, specialized in curriculum and evaluation (Universidad Mayor, Chile), as well as a diploma in chemistry for science and chemistry teachers (Pontificial Catholic University of Chile). 